\title{
Experimental and Calculation Determination of Crane Rail Fatigue Life
}

\author{
Peter Bigoš ${ }^{1 *}$, Eva Faltinová ${ }^{2}$ \\ 1.2 Department of Machine Design, Transport and Logistics Letná 9, 04001 Košice, Slovak republic
}

\section{BIOGRAPHICAL NOTES}

prof. Ing. Peter Bigoš, CSc. is a university professor nominated in the branch of science "Transport and Handling Engineering". He is a head of the Department of Machine Design, Transport and Logistics at the Faculty of Mechanical Engineering, Technical University of Košice. He graduated at the Faculty of Mechanical Engineering of the former Technical College in Košice (1973). Dissertation thesis he defended in 1980 and in 1983 he was designated as a docent (associate professor). In 1991 he defended his inaugural dissertation at the Technical University of Košice. In the framework of his study stages he visited TU Miskolc, VH Dresden (1981), Polytechnika Rzeszowska (1983), Ruhr Universität Bochum (1989), Imperial College London (1993), TU Budapest (1997). He is a vice-chairman of the "Common professional commission for PhD.-study" in the branch of study "Transport Machines and Machinery" and he is a member of professional commission in the branch "Forensic Engineering", too. He is also member of several advisory boards of domestic and foreign professional journals, as well as he is a guarantor of international and domestic conferences about transport machines and logistics.

Ing. Eva Faltinová, PhD. is an assistant lecturer at the Department of Machine Design, Transport and Logistics at the Faculty of Mechanical Engineering, Technical University of Košice. He graduated at the Department of Transport and Handling Machines, which was a predecessor of the above-mentioned Department in 1983. The PhD.-degree she obtained with the dissertation thesis targeted on the theoretical and practical questions concerning reliability and durability of supporting structures for the transport machines. Her research activities are focused on experimental verification and calculation of durability for steel supporting structures of the hoisting machines and machineries.

\section{KEY WORDS}

Crane rail, calculation analysis of stress, tensometric measurement, accumulation of fatigue failure

\section{ABSTRACT}

This paper presents the assessment of crane rail load-bearing structure by tensometry in a metallurgical plant under hard working conditions and it assigns the remaining fatigue life of load-bearing structures, moreover it makes a proposal on its further performance.

\section{Introduction}

Crane rails used as driving systems of bridge cranes are enormly stressed during work mainly if these cranes are not only applied in load lifting but also as transport means. Typical operations where cranes are applied as transport means as well are 
those in metallurgical plants.

To solve this given issue a crane crail used for driving 4 cranes with load - bearing capacity from $14 \mathrm{t}$ to $32 \mathrm{t}$ was chosen in a particular metallurgical plant. The main tasks performed by these cranes concern loading of sheet coils on the lorries and wagons.

\section{Experimental Section 2.1 Crane rail description}

The examined part of the crane rail consists of simple load-bearing structure with I-profile $1800 \mathrm{~m}$ high and $18000 \mathrm{~mm}$ long. The different load-bearing structures are vertically reinforced, screwed to columns and at the same time they are interconnected by screw up to the third of the structure length. Under the simple load-bearing structures with $18000 \mathrm{~mm}$ length the crane brakes can be found in rows (Fig.1). It was necessary to adjust the distribution of crane brakes under the particular load-bearing structures in the way to be transversally welded to the bottom flange of I profile steel load-bearing structure in a small distance from the structure center both on the right and left in order to carry the brake forces from the main structure to the crane brake.

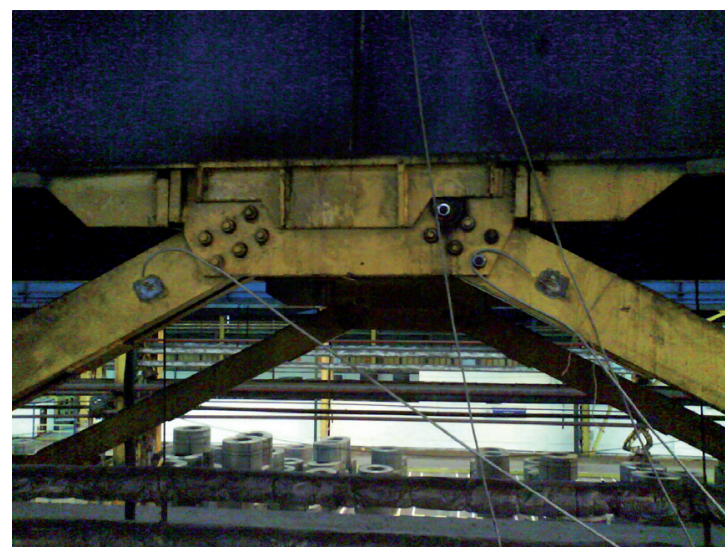

Fig. 1: Simple load-bearing structure $18000 \mathrm{~mm}$ long with crane brake

\subsection{Computational analysis of crane rail stress}

The aim of stress calculation simulation of the crane rail was to provisionally estimate the potential maximum stress in those places where the recorders are placed on the bottom flange of the crane rail focusing on measured arrays. The calculation models were created for application of Finite Element Method in the program COSMOS/M. For simulation the calculation models of rail arrays both with crane brake and without it were created.

\subsection{Application of the FEM model}

For modelling rails of both types there were applied volume elements TETRA10. In Fig. 2 the detail of finite elements for the net framework is presented in contact point of rail with crane brake and in Fig. 3 the detail of finite elements for the net framework is demonstrated in the middle of array span without crane brake.

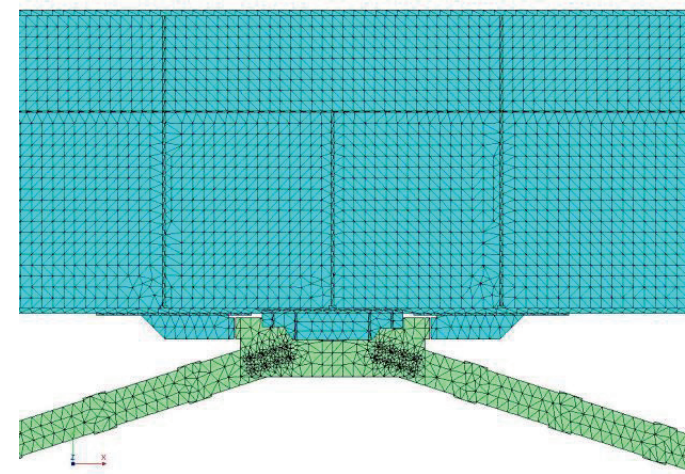

Fig. 2: Detail of rail support by crane brake in array 69-70.

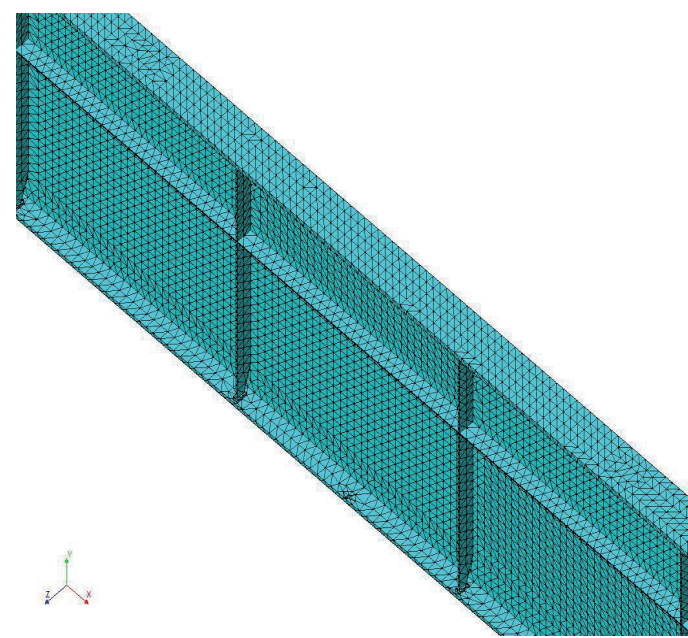

Fig. 3: Detail of finite elements for the net framework in the model of array span without crane brake.

\subsection{Evaluation of calculation analysis results}

The calculation results by FEM were evaluated in the following expressions of direct longitudinal stress $\sigma x$, caused by bending stress of rail due to orientation of recorders which were applied in tensometric measurement. 


\subsection{Experimental measurement}

Due to previous theoretical analysis and visual observation of the crane rail the researchers proposed the method of experimental deformation determination and the following stress definition. The places of recorders distributed in arrays No. 6970 and No. 70-71 are presented in Fig. 4.

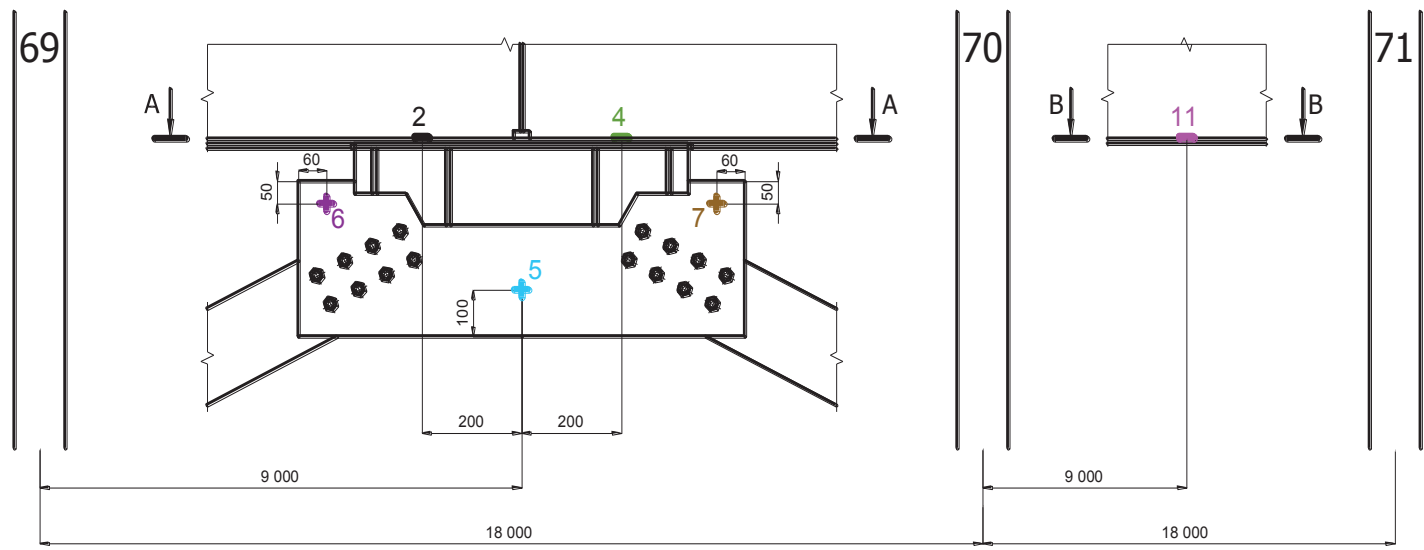

A-A

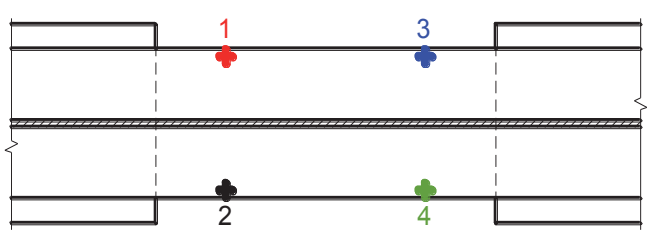

B - B

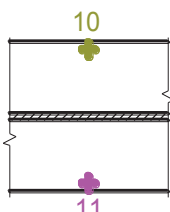

Fig. 4: Distribution of tensometric recorders on the load-bearing structure with crane brake in array 69-70 and on simple structure without crane brake in array $70-71$.

The tensometric recorders HBM 6/120XY11 with Ohm value 120 and with constant deformation response 2.04 were applied for measurements. The recorders were applied by using tensometric sealant HBM X60. The measuring and evaluation chain was created due to Fig. 5. After levelling of apparatus (Fig.4) the recorders were conserved by protecting coating SG 250 (f. HBM).

Due to measured values of proportional deformation accumulation in different measurement modes applying the software CATMAN 2.1 the time modifications of direct stress accumulation in measured points were demonstrated and printed due to Fig. 4.

The methodology of experiment consisted of 7 measurements in 7 different stress modes with weight load $12500 \mathrm{~kg}$.

The total number of evaluated time records of direct stress in different points of measurements was 63 taking into consideration the chosen stress modes.

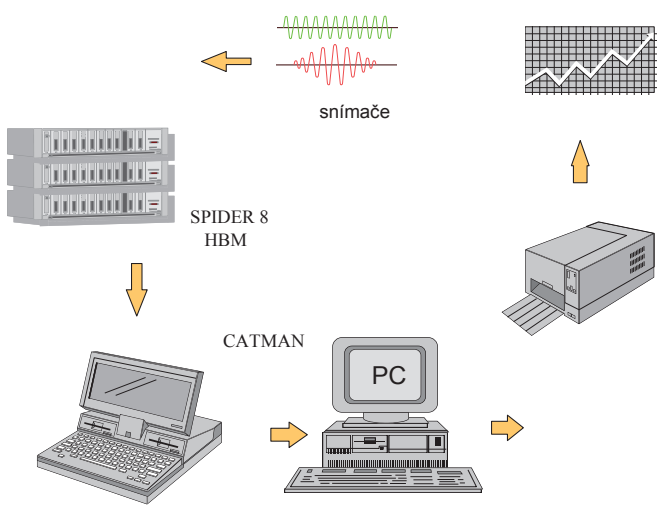

Fig. 5: Measuring and evaluation chain.

\section{Results and Discussion \\ 3.1 Determination of durability and residual durability for load-bearing}

Our assessment of the fatigue failure due to material fatigue was completed in comply with the standard STN 73 1401. The aim of the structure as- 
sessment considering the fatigue limit state is to provide with acceptable probability that until the determined fatigue life of the structure it will not be damaged or violated due to material fatigue.

The calculation was based on data about stress cycles of load- bearing structures during the defined fatigue life of the crane rail i.e. from 1966 to 2005. Due to obtained results from the metallurgical plant the analysis of stress cycles of the examined crane rail was carried out, the results of which are presented in Table 1 divided according to different arrays between columns. The presented table served for estimation of remaining fatigue life.

Table 1: Number of cycles according to arrays between columns.

\begin{tabular}{|c|c|c|}
\hline \multirow{2}{*}{$\begin{array}{l}\text { Load-bearings } \\
\text { between columns }\end{array}$} & \multicolumn{2}{|c|}{ Number of cycles 1966 - 2005} \\
\hline & $\begin{array}{l}\text { Cranes with } \\
\text { average load of } \\
11000 \mathrm{~kg}\left(\mathrm{n}_{1}\right)\end{array}$ & $\begin{array}{l}\text { Cranes without } \\
\text { load }\left(n_{2}\right)\end{array}$ \\
\hline $55-58$ & 138146 & 138146 \\
\hline $58-68$ & 2993147 & 2993147 \\
\hline $68-76$ & 1473549 & 1473549 \\
\hline Total & 4604842 & 4604842 \\
\hline
\end{tabular}

Assessing the fatigue life of the examined loadbearing structures of the crane rails we had to take into consideration the results of measured time path of direct stress accumulation and the calucations in comply with the standard STN 731401.

Due to the above standard it is requirable to consider detail number ČD 206 for the simple loadbearing structure of the crane rail without crane brake which can be characterized by detail category KD 125.

Concerning the simple load-bearing structure with crane brake with bottom flange cross section $300 \times 26 \mathrm{~mm}$ it is necessary to consider between detail number ČD 417 with detail category KD 50 and detail number ČD 418 with detail category KD 36 in comply with the standard STN 73 1401. Applying the linear interpolation we can get to the detail category KD 45. Data required for the determination of fatigue life for KD 45 and KD 125 are presented in Table 2.

Further the remaining fatigue life of the crane rail load-bearing structures was determined according to mode introduced in the standard STN 731401. The results concerning the different load-bearing structures are presented in Table 3.

Table 2: Numerical values of applied fatique life curves.

\begin{tabular}{|c|c|c|c|c|}
\hline \multirow{3}{*}{$\begin{array}{l}\text { Detail } \\
\text { stress }\end{array}$} & \multirow{2}{*}{$\begin{array}{l}\text { Detail } \\
\text { category KD }\end{array}$} & \multicolumn{3}{|c|}{ Stress range } \\
\hline & & $\mathrm{N}_{\mathrm{M}, \mathrm{ko}}$ & $N_{D}=5.10^{6}$ & $N \geq N L=108$ \\
\hline & $\Delta \sigma_{c}(\mathrm{MPa})$ & $\begin{array}{l}\Delta \sigma_{\mathrm{M}, \mathrm{KD}} \\
(\mathrm{MPa})\end{array}$ & $\begin{array}{l}\Delta \sigma_{\mathrm{D}} \\
(\mathrm{MPa})\end{array}$ & $\Delta \sigma_{\mathrm{L}}(\mathrm{MPa})$ \\
\hline \multirow{2}{*}{$\begin{array}{l}\text { Direct } \\
\text { stress }\end{array}$} & 45 & 452 & 33 & 18 \\
\hline & 125 & 232 & 92 & 51 \\
\hline
\end{tabular}

Table 3: Numerical values of applied fatigue life curves.

\begin{tabular}{|l|l|}
\hline $\begin{array}{l}\text { Load-bearings between } \\
\text { columns }\end{array}$ & \multicolumn{1}{l|}{$\begin{array}{l}\text { Accumulation of fatigue } \\
\text { failure }\end{array}$} \\
\hline $55-58^{*}$ & 0,3909 \\
\hline $55-58$ & 0,01287 \\
\hline $58-68^{*}$ & 8,47 \\
\hline $58-68$ & 0,28 \\
\hline $68-76^{*}$ & 4.169 \\
\hline $68-76$ & 0,137 \\
\hline
\end{tabular}

Note: index * labels load-bearings with crane brake

\section{Conclusion}

Due to tensometric measurements and assessment of the obtained results, further after considering the valid standards the following conclusions can be drawn:

- Considering the measured stress values in the array 69-70 of simple load-bearing structure of the crane rail supported by crane brake it can be determined that the fatigue life of it is up to $95 \%$ of probability totally ended. This is proved by the fact of the fatigue crack on the bottom flange which is propagating (Fig. 6).

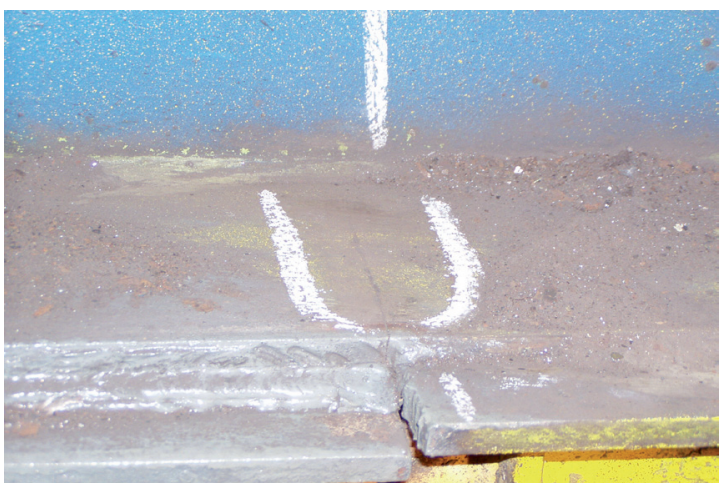

Fig. 6: Photo documentation of fatigue crack 
- In regard to measured stress values in the array 70-71 of simple load-bearing structure of the crane rail with crane brake the fatigue life with $95 \%$ of survival probability is appropriate (getting near to infinity).

- The fatigue life of simple load-bearing structures of the crane rails supported by crane brake in the array 55-56 is not totally ended with $95 \%$ of survival probability and these load-bearing structures can be applied in operations (arrays 55-56 are rarely used).

- The fatigue life of simple load-bearing structures of the crane rails supported by crane brake in the arrays 62-63, 69-70 and 74-75 is ended with $95 \%$ of survival probability and it is requirable to change them (put them out of service).

\section{Acknowledge}

This paper was completed within the research project VEGA 1/0356/11 Innovative processes in structure of transport device units and optimalization of material flows and logistics aimed at energy saving and reliability enhancement for practical applications.

\section{References}

[1] TREBUŇA,F. - BIGOŠ,P.: Intenzifikácia technickej spôsobilosti tažkých nosných konštrukcií. Vienala, Košice,1998, ISBN 80967325-3-6

[2] BIGOŠ,P:: Dynamická pevnost' a životnost'. Alfa, Bratislava, 1987

[3] HAIBACH, E.: Betriebsfestigkeit. VDI-Verlag GmbH, Düsseldorf,1989

[4] ČAČKO,J.- BÍLÝ,M.- BUKOVECZKY,J.: Meranie, vyhodnocovanie a simulácia prevádzkových náhodných procesov. Veda, Bratislava,1984

[5] PUŠKÁR,A. - GOLOVIN,S.: Kumulácia poškodenia $\vee$ procese únavy. Veda, Bratislava, 1981

[6] KLESNIL,M.- LUKÁŠ,P.: Únava kovových materiálů při mechanickém namáhání. Academia, Praha, 1975

[7] DYLAG,Z. - ORLOS,Z:: Únava materiálu a její zkoušení. SNTLNakladatelství technické literatury, Praha, 1968

[8] SINAY,J.- BIGOŠ,P.- BUGÁR,T:: Experimentálne metódy a skúšanie strojov. Alfa, Bratislava,1989

[9] BÍLY,M.: Únavové vlastnosti materiálov a súčastí. VŠT Košice, 1978

[10] LUKÁŠ,P.: Únava kovových materiálů při mechanickém namáhaní. Academia, Praha, 1975

[11] STN 731401 - Navrhovanie ocelových konštrukcií. SÚTN, 1998 